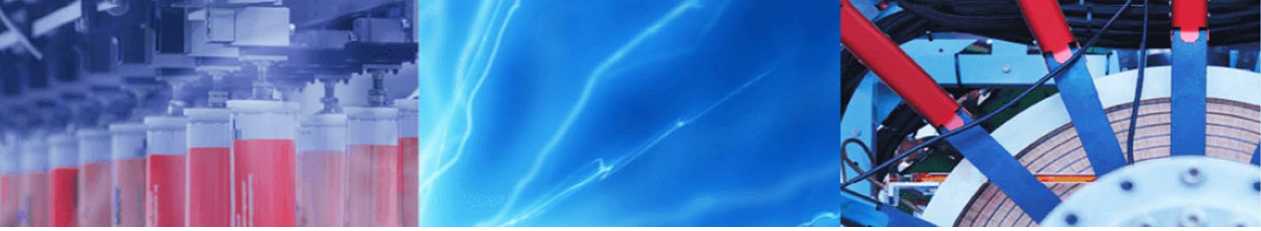

Research Article

\title{
A simple chemical precipitation of ceria based (Sm doped-CGO) nanocomposite: structural and electrolytic behaviour for LT-SOFCs
}

\author{
Karthik Kannan $^{1}$ - D. Radhika ${ }^{2}$ A. S. Nesaraj ${ }^{3} \cdot$ V. Revathi $^{4} \cdot$ Kishor Kumar Sadasivuni $^{1}$
}

Received: 7 April 2020 / Accepted: 10 June 2020 / Published online: 15 June 2020

(c) Springer Nature Switzerland AG 2020

\begin{abstract}
Rare-earth doped metal oxide nanocomposites were become very unique and tend to show abundant performance in all types of fields such as electrochemical, photocatalytic, and biological. Gadolinium and Samarium co-doped ceria i.e., $\mathrm{Ce}_{1-\mathrm{x}} \mathrm{Gd}_{1-\mathrm{y}} \mathrm{O}_{2-\delta}-\mathrm{Ce}_{1-\mathrm{x}} \mathrm{Sm}_{-\mathrm{y}} \mathrm{O}_{2-\delta}[\mathrm{x}=0.2, \mathrm{y}=0.8]$ nanocomposite was synthesized by co-precipitation method for various applications. The formation of fluorite cubic crystal structure was observed and functional group analysis was revealed by XRD and FTIR correspondingly. SEM with EDAX was revealed the morphological and chemical composition analysis of the prepared nanocomposite. Impedance studies were completed at particular conditions and proved as a suitable electrolyte for low temperature solid oxide fuel cell (LT-SOFC) applications.
\end{abstract}

Keywords Multi-doping $\cdot$ Nanocomposite $\cdot$ Chemical precipitation $\cdot$ C-TAB

\section{Introduction}

SOFCs are unresolved alternates to established power sources; however, they undergo few technical issues like larger temperature processes $\left(1000^{\circ} \mathrm{C}\right)$, which diminish them from commercialization. Presently, uncountable works have been assigned to enlarge a low or transitional temperature SOFCs functioning at $500-800^{\circ} \mathrm{C}$. Due to reducing the operating temperature can detain the dilapidation of components and enlarge the variety of appropriate material assembly; it also attends to improve cell sturdiness and lessen the system expense. Therefore, innovative materials with upright functioning conditions like chemically, mechanically, and compatible also level of conductance have to be recognized and industrialized principally for purpose in LT or ITSOFCs [1, 2]. The price reduction, immediate operation, and greater robustness of IT-SOFCs ought to create them well matched with purposes such as remote power production; uninterruptible power supplies (UPS), and auxiliary power units (APU).

Several metal oxide nanocomposites have wide purposes such as gas and chemical sensors, wastewater remediation, and biological activity. With respect to ecological remediation, nanomaterials have prevalent and become capable material owing to their tapered bandgap, economically cheap, non-toxicity, thermally, and chemically stable $[3,4]$. YDC and SDC were propositioned as possible materials as anode for IT-SOFCs due to their typical mixed ionic-electronic conductive nature $[5,6]$. It was found that combined metal oxides might demonstrate exceptional elevated electronic, ionic conductivity, and catalytic activity, consecutively, which could maintain to accomplish raised power production [7-10]. Present literature on nanotechnology exposes that numerous nanoparticles (NPs) with $\mathrm{CeO}_{2}, \mathrm{NiO}, \mathrm{CGO}, \mathrm{CYO}$ have been broadly utilized in biological applications [11-14]. Metal oxide NPs fascinated numerous young scientists due to

$\triangle$ D. Radhika, radhikadv8@gmail.com | 1 Center for Advanced Materials, Qatar University, P.O. Box 2713, Doha, Qatar. ${ }^{2}$ Department of Chemistry, Faculty of Engineering and Technology, Jain-Deemed to be University, Jakkasandra, Ramnagara, Karnataka 562112, India. ${ }^{3}$ Department of Chemistry, Karunya Institute of Technology and Sciences, Coimbatore, Tamil Nadu 641 114, India. ${ }^{4}$ Department of Physics, Jaya College of Arts and Science, Thiruninravur, Chennai, India. 
their noticeable unusual physical, chemical properties, and non-toxic feature. The metal oxide NPs are also eminent in the tradition of pharmaceutical and regenerative medication technologies [15-17].

Amongst numerous metal oxide NPs, cerium oxide $\left(\mathrm{CeO}_{2}\right) \mathrm{NPs}$ are creatures widely employed owing to their lesser bandgap, chemical stability, and electrochemical action $[1,2]$. Such impending properties correlated with the $\mathrm{CeO}_{2}$ with rare earth dopants defended the use of nanocomposites in dissimilar fields resembling sensing applications, solid oxide fuel cells, photocatalytic, and biological activities [18-20]. Plentiful ways have been executed such as ultra-sonication, ball milling, microwave, sol-gel, mechanical alloying and chemical-precipitation, etc. for the preparation of nanocomposite materials from the mixed metal oxide precursors. [21-24]. From above all well-known methods, the chemical-precipitation process is used as a competent technique for the production of nanomaterials, owing to effortlessness. This move toward is extra operative for yielding homogeneity, particularly sample without impurities, tiny particle size, and a short period of time [25-27].

Ceria with rare earth metal oxides combination is of considerable attention for potential applications in SOFCs due to their change in morphology and outstanding ionic conductivity $[16,17]$. Recently, nanocomposite materials have been used as electrolyte materials for LTSOFC. A comparative study with single-doping electrolytes (SDC, YSZ) and multi doping or nanocomposite electrolyte encompass lots of interface sections amid the two constituent phases [26, 27]. Here, rare earth based ceria doped nanocomposite was synthesized thoroughly using surfactant (C-TAB) as described in previous literature $[28,29]$. It contrasts with the design of Sm dopedCGO nanocomposite using wet chemical synthesis using CTAB surfactant. The prepared composite was investigated to know structural, morphological and electrochemical performance.

\section{Experimental}

\subsection{Materials and methodology}

The starting chemicals consumed in this process were the analytical grade without any additional purification. The cerium nitrate hexahydrate, gadolinium oxide, samarium oxide, and C-TAB were used as a precursor material and sodium hydroxide, nitric acid, and ethanol employed as a precipitating agent. The experiment involved in the synthesis of aqueous solutions as accounted previously [20].

Principally, $\mathrm{NaOH}$ was blended with $\mathrm{CTAB}$ and then $\mathrm{Ce}\left(\mathrm{NO}_{3}\right)_{3}, \mathrm{Gd}\left(\mathrm{NO}_{3}\right)_{3}$, and $\mathrm{Sm}\left(\mathrm{NO}_{3}\right)_{3}$ solutions were accordingly included. They subjected to stirring for two-three hours at room temperature (RT) with $\mathrm{pH}>9[30,31]$. The resulting precipitate $\left(\mathrm{Ce}(\mathrm{OH})_{4}+\mathrm{Gd}(\mathrm{OH})_{3}+\mathrm{Sm}(\mathrm{OH})_{3}\right.$ with $\mathrm{C}-\mathrm{TAB}$ ) was separated by filtration using filter paper, washed and dehydrated at $50-100^{\circ} \mathrm{C}$ for two-three hours and left for overnight. The acquired material was calcined for $2 \mathrm{~h}$ at various temperatures till $750^{\circ} \mathrm{C}$. The method of preparation was followed as reported in earlier work and it was shown in Fig. 1 [5].
Fig. 1 Synthesis of S-CGO nanocomposite by chemical precipitation route

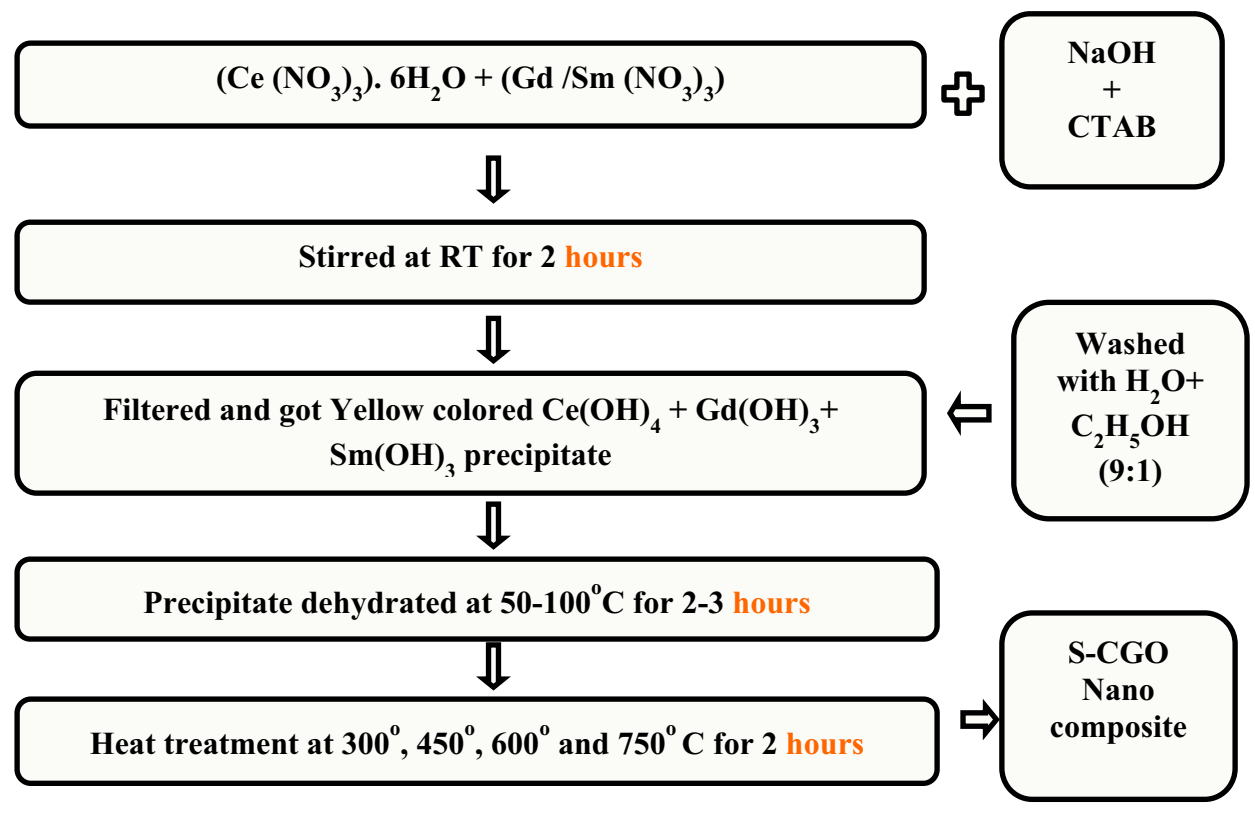




\subsection{Reaction mechanism}

The subsequent steps involved in the production of nanocomposite throughout the experiment can be written and was shown below: as reported earlier and the thermogram as shown in the Fig. 2.

From the above TGA spectrum, it was found that the

\section{Reaction mechanism for S-CGO nanocomposite}

$$
\begin{aligned}
& \text { (i) } 0.38 \mathrm{NaOH} \rightarrow 0.38 \mathrm{Na}_{(\mathrm{aq})}^{+}+0.38 \mathrm{OH}_{(\mathrm{aq})}^{-} \text {, } \\
& \text { (ii) } 0.08 \mathrm{Ce}\left(\mathrm{NO}_{3}\right)_{3} \cdot 6 \mathrm{H}_{2} \mathrm{O}_{(\mathrm{s})} \rightarrow 0.08 \mathrm{Ce}_{(\mathrm{aq})}^{3+}+0.24 \mathrm{NO}_{3(\mathrm{aq})}^{-}+6 \mathrm{H}_{2} \mathrm{O}_{(\mathrm{aq})} \text {, } \\
& \text { (iii) } \left.0.02 \mathrm{Gd} \mathrm{NO}_{3}\right)_{3} \rightarrow 0.02 \mathrm{Gd}_{(\mathrm{aq})}^{3+}+0.06 \mathrm{NO}_{3(\mathrm{aq})}^{-} \\
& \text {(iv) } 0.02 \mathrm{Sm}\left(\mathrm{NO}_{3}\right)_{3} \rightarrow 0.02 \mathrm{Sm}^{3+}{ }_{(\mathrm{aq})}+0.06 \mathrm{NO}_{3(\mathrm{aq}) \text {, }}^{-} \\
& \text {(v) } 0.08 \mathrm{Ce}_{(\mathrm{aq})}^{3+}+0.02 \mathrm{Gd}^{3+} / \mathrm{Sm}^{3+}+0.38 \mathrm{OH}_{(\mathrm{aq})}^{-}+\mathrm{xH}_{2} \mathrm{O}_{(\mathrm{aq})} \rightarrow 0.08 \mathrm{Ce}(\mathrm{OH})_{4} \cdot \mathrm{x} \mathrm{H}_{2} \mathrm{O}_{(\mathrm{s})} \downarrow \\
& +0.02 \mathrm{Gd} / \mathrm{Sm}(\mathrm{OH})_{3} \cdot \mathrm{X} \mathrm{H}_{2} \mathrm{O}_{(\mathrm{s})} \\
& \downarrow 50-100^{\circ} \mathrm{C} \\
& \text { (vi) } 0.08 \mathrm{Ce}(\mathrm{OH})_{4} \cdot \mathrm{xH}_{2} \mathrm{O}_{(\mathrm{s})}+0.02 \mathrm{Gd} / \mathrm{Sm}(\mathrm{OH})_{3} \cdot \mathrm{x} \mathrm{H}_{2} \mathrm{O}_{(\mathrm{s})} \rightarrow 0.08 \mathrm{Ce}(\mathrm{OH})_{4(\mathrm{~s})}+0.02 \\
& \mathrm{Gd} / \mathrm{Sm}(\mathrm{OH})_{3(\mathrm{~s})}+\mathrm{x} \mathrm{H}_{2} \mathrm{O}_{(\mathrm{g})} \uparrow \text {, } \\
& \downarrow 300^{\circ} \mathrm{C} / 450^{\circ} \mathrm{C} / 600^{\circ} \mathrm{C} / 750^{\circ} \mathrm{C} \text { for } 2 \text { hours } \\
& \text { (vii) } 0.08 \mathrm{Ce}(\mathrm{OH})_{4(\mathrm{~s})}+0.02 \mathrm{Gd} / \mathrm{Sm}(\mathrm{OH})_{3} \rightarrow \mathbf{C e}_{\mathbf{0 . 8}} \mathbf{G d}_{\mathbf{0 . 2}} \mathbf{O}_{\mathbf{2 - \delta}}-\mathbf{C e}_{\mathbf{0 . 8}} \mathbf{S m}_{\mathbf{0 . 2}} \mathbf{O}_{\mathbf{2 - \delta}}
\end{aligned}
$$

\subsection{Characterization techniques}

The thermal behaviour of the synthesized precursor sample was examined by Perkin Elmer TGA 7 under $\mathrm{N}_{2}$ atmosphere at $10{ }^{\circ} \mathrm{C} / \mathrm{min}$ of heating rate. The powder XRD measurements were done via a Shimadzu XRD 6000 $X$-ray diffractometer. Functional group analysis was carried out by the FTIR spectrometer (Bruker IFS $66 \mathrm{~V}$ ). The size of the particles for prepared samples was investigated using Malvern Particle Size Analyzer. The morphological study of samples was done using the JEOL Model JSM-6360 SEM. The bulk conductivity was estimated using impedance analysis.

\section{Results and discussion}

\subsection{TGA analysis}

The synthesized precursor sample $\left[\mathrm{Ce}(\mathrm{OH})_{4}+\mathrm{Gd}(\mathrm{OH})_{3}\right.$ $+\mathrm{Sm}(\mathrm{OH})_{3}$ with $\left.\mathrm{CTAB}\right]$ with an initial mass of $13-14 \mathrm{mg}$ was situated in pt crucible and proceed for investigation weight loss initiates to show from the beginning stage itself. The nanocomposite (thermal decomposition) can be distributed into 4 distinct regions as elucidated in the

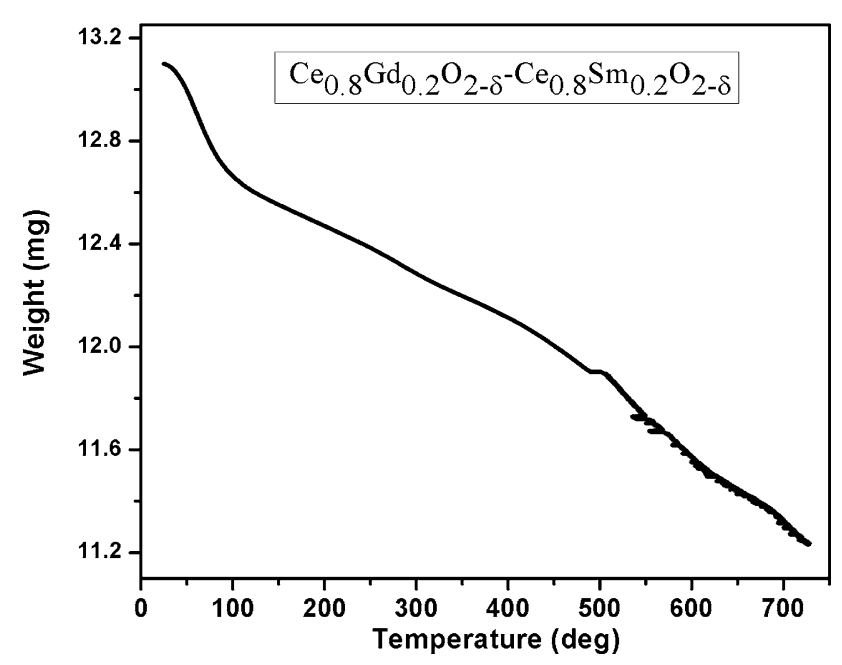

Fig. 2 TGA spectrum of the starting material 
Table 1 Summary of weight loss by TGA

\begin{tabular}{|c|c|c|c|}
\hline $\begin{array}{l}\text { Phase/sec- } \\
\text { tion }\end{array}$ & Temperature $\left({ }^{\circ} \mathrm{C}\right)$ & Weight loss (\%) & Explanation \\
\hline I & 100 & 2 & Loss of water, solvent \\
\hline II & $100-500$ & $5-6$ & Composite phase development \\
\hline III & Amid $500-700$ & Higher than 6 & $\begin{array}{l}\text { Carbon/nitrogen-based complexes } \\
\text { (decomposition) }\end{array}$ \\
\hline IV & Approximately 700 & $\begin{array}{l}\text { Immovability in } \\
\text { weight loss }\end{array}$ & Phase-pure creation of nanocomposite \\
\hline
\end{tabular}

Table 2 Weight loss change observed from the TGA of starting material

\begin{tabular}{lllll}
\hline Material & $\begin{array}{l}\text { Weight } \\
\text { at } 25^{\circ} \mathrm{C} \\
\text { (initial) } \\
(\mathrm{mg})\end{array}$ & $\begin{array}{l}\text { Weight } \\
\text { at } 700 \\
{ }^{\circ} \mathrm{C}(\text { final) } \\
(\mathrm{mg})\end{array}$ & $\begin{array}{l}\text { Weight } \\
\text { loss (total) } \\
(\mathrm{mg})\end{array}$ & $\begin{array}{l}\text { Total } \\
\text { weight loss } \\
(\%)\end{array}$ \\
\hline $\mathrm{Ce}_{1-\mathrm{x}} \mathrm{Gd}_{1-\mathrm{y}} \mathrm{O}_{2-\delta^{-}}$ \\
$\begin{array}{l}\mathrm{Ce} \mathrm{e}_{1-\mathrm{x}} \mathrm{Sm}_{-\mathrm{y}} \mathrm{O}_{2-\delta} \\
{[\mathrm{x}=0.8, y=0.2]}\end{array}$ & & 11.23 & 1.86 & 19 \\
\hline
\end{tabular}

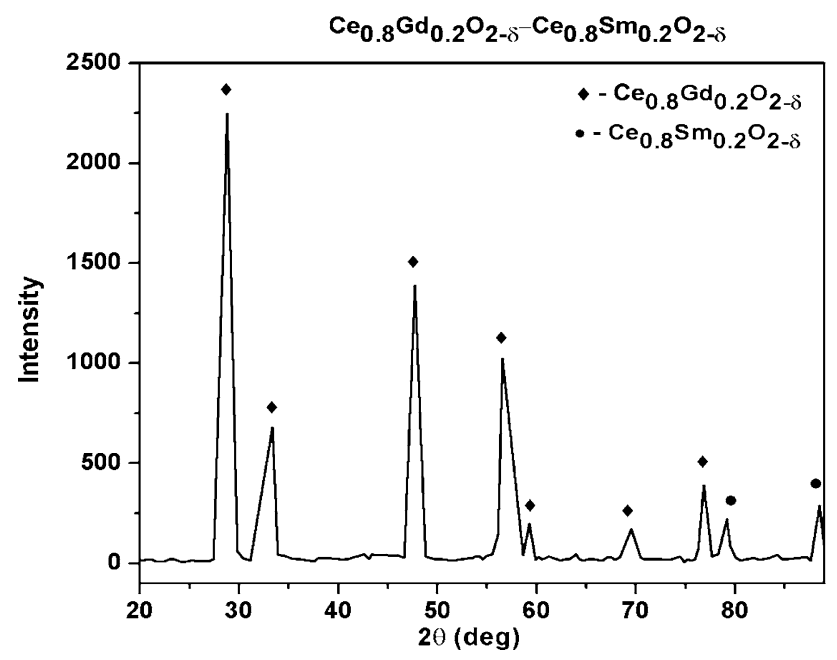

Fig. 3 XRD pattern of the prepared sample

previous research report $[5,32]$ and also the weight loss change observed for the precursor material obtained from the TGA data signified in Tables 1 and 2 correspondingly.

\subsection{XRD analysis}

The XRD pattern of the calcined nanocomposite reveals the creation of fluorite cubic well crystallined single-phase as shown in Fig. 3 [19, 33-35]. There is no secondary phase were scrutinized in the XRD pattern of prepared sample and the crystallographic planes monitored at 2 theta values of $28.8^{\circ}, 33.3^{\circ}, 47.7^{\circ}, 56.5^{\circ}, 59.3^{\circ}, 69.6^{\circ}, 76.8^{\circ}, 79.2^{\circ}$ and
Table 3 The crystallographic parameters obtained on prepared nanocomposite

\begin{tabular}{ll}
\hline Lattice parameters & $\begin{array}{l}\text { Doped } \mathrm{CeO}_{2} \text { phase } \\
\text { of nanocomposite }\end{array}$ \\
\hline Crystallite structure & Cubic \\
Lattice constant ' $\mathrm{a} \mathrm{a}^{\prime}(\AA)$ & 5.404 \\
Cell volume $\left(\AA^{3}\right)$ & 157.814 \\
Theoretical density $(\mathrm{g} / \mathrm{cc})$ & 8.175 \\
Crystallite size $(\mathrm{nm})$ & 20.8
\end{tabular}

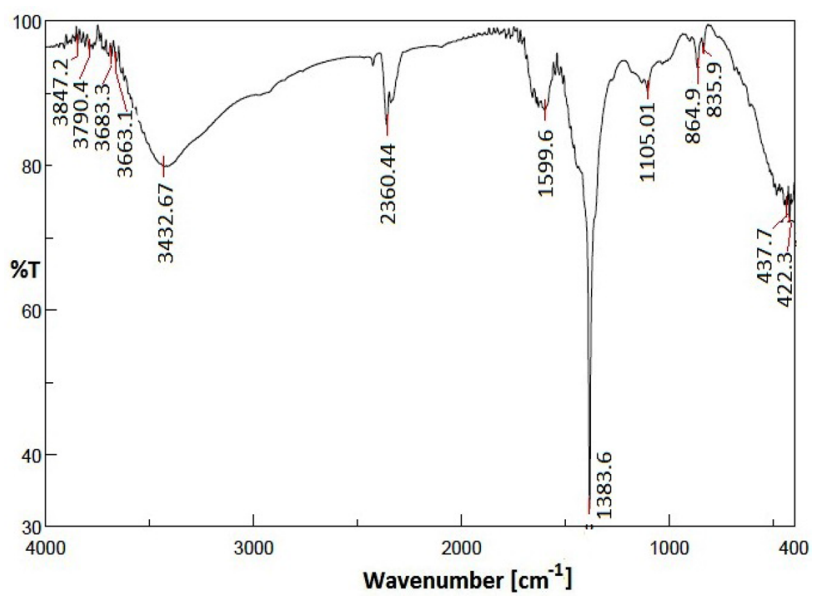

Fig. 4 FTIR spectrum of prepared nanocomposite

$88.5^{\circ}$ shown the intensity peaks with following $\mathrm{h} \mathrm{k}$ val-

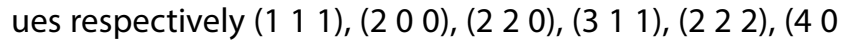
0), ( (3 3 1 1), (4 $\left.\begin{array}{lll}4 & 0\end{array}\right)$ and (4 22 2). All these values are in good agreement with the customary JCPDS card No: 81-0792 and indicated that the $\mathrm{CeO}_{2}$ phase is pure [36]. And also there were few more crystallographic planes observed at 2 theta values of $79.2^{\circ}$ and $88.5^{\circ}$ shown the intensity of peaks with following $\mathrm{h} \mathrm{k}$ I values respectively (4 20 ) and (4 2 2). These peaks were represented with the dot symbol and it revealed that the presence of Sm-doped ceria and they were well matched with the literature. The 
Table 4 The FTIR peak assignments of prepared nanocomposite

\begin{tabular}{llllll}
\hline Material & \multicolumn{5}{l}{ Distinctive peaks $\left(\mathrm{cm}^{-1}\right)$} \\
\cline { 2 - 6 } & Gd-O \& Sm-O & $\mathrm{C}-\mathrm{H}$ & $\mathrm{CO}_{2}$ (Atmospheric) & $\begin{array}{l}\text { Bending vibra- } \\
\text { tion of } \mathrm{H}-\mathrm{O}-\mathrm{H}\end{array}$ & $\begin{array}{l}\text { Stretching } \\
\text { vibration of } \\
\mathrm{O}-\mathrm{H}\end{array}$ \\
\hline Reference peaks & Near 400 & 1383 & $2360 \& 1110$ & 1600 & 3400 \\
Reference & {$[26]$} & {$[40]$} & {$[41,42]$} & {$[35-41]$} & {$[37-41]$} \\
S-CGO & $422 \& 437$ & 1383.6 & 2360.4 & 1599.6 & 3432.6 \\
\hline
\end{tabular}

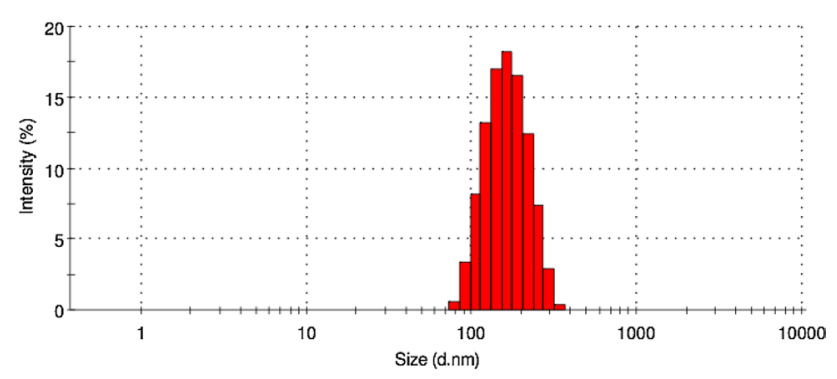

Fig. 5 Particle size analysis of the prepared nanocomposite

calculated d-spacing values for S-CGO nanocomposite were also matched with the earlier research reports. The crystallographic parameters were calculated and displayed in Table 3.

\subsection{FTIR analysis}

The FTIR spectrum was done by the $\mathrm{KBr}$ technique at RT (Fig. 4). The FTIR allocated distinctive peaks are registered in Table 4.

\subsection{Particle size characteristics}

S-CGO nanocomposite was exposed to study particle size analysis followed by $0.30 \mathrm{~g}$ of material sonicated in 30 $\mathrm{mL}$ deionized water for around $15 \mathrm{~min}$, and the plot was shown in Fig. 5.

From this analysis, it is revealed that the size of particles is in the range of $180.2-243.1 \mathrm{~nm}$. The data obtained from particle size analysis (Table 5). Due to calcination at hightemperature, the presence of bigger particles (>200 nm) appeared in the sample [36].

Table 5 Particle characteristic data obtained on S-CGO nanocomposite

\begin{tabular}{|c|c|c|c|c|c|c|c|}
\hline \multirow[t]{2}{*}{ Sample } & \multicolumn{3}{|l|}{ Peak 1} & \multicolumn{3}{|l|}{ Peak 2} & \multirow[t]{2}{*}{ Avg. particle size (nm) } \\
\hline & Size $(d)(n m)$ & Intensity (\%) & Width (d) (nm) & Size $(d) c(n m)$ & Intensity (\%) & Width (d) (nm) & \\
\hline S-CGO & 177.0 & 100 & 63.67 & - & - & - & 180.3 \\
\hline
\end{tabular}
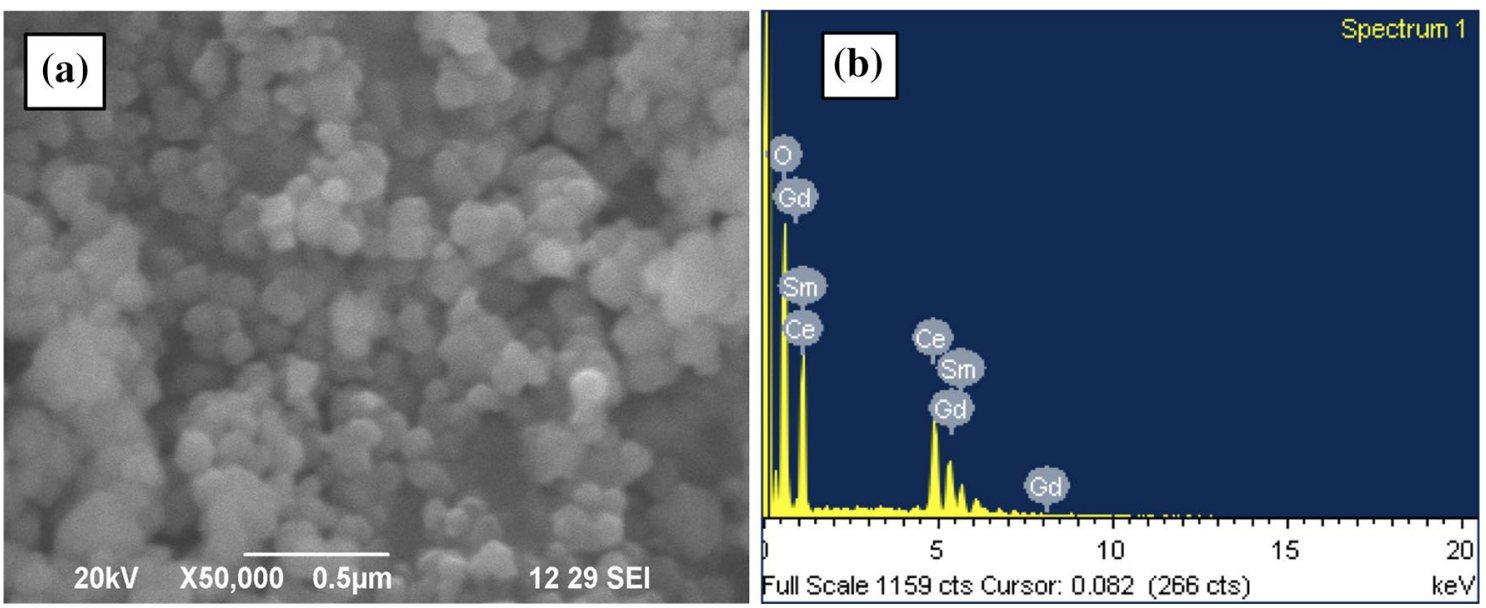

Fig. 6 a SEM and b EDAX data obtained on S-CGO nanocomposite 


\subsection{SEM and EDAX studies}

The SEM and EDAX pictures obtained on S-CGO are displayed in Fig. 6a, b and SEM photograph has taken at 35,000 resolutions. The surface morphology of prepared nanocomposite revealed the shape and size of the particle and pore. From Fig. $6 a$, it noticed that the grain size is in the range from 40 to $70 \mathrm{~nm}$. Due to calcination at high temperatures, there is the presence of a few bigger particles in the samples $[26,43-45]$. It is a recognized reality that the complement of the CTAB surfactant diminishes the opportunity of tremendous agglomeration to attain superior nanocomposite. The EDAX exposed the occurrence of Ce (44.65\%), Gd (5.72\%), Sm (3.31\%), and O $(46.32 \%)$ as shown in Fig. 6b. No additional peaks were shown in the spectrum signifying the absence of chemical impurities in the sample [25-27].

\subsection{Impedance analysis}

Employing hydraulic pressure pelletizer, pellets (compacts) from the synthesized nanocomposite with the thickness $(2 \mathrm{~mm})$ and diameter $(10 \mathrm{~mm})$ were equipped by operating pressure (1.2 ton). Ahead of the impedance capacities to get an extremely densified state, the sample was annealed at $750{ }^{\circ} \mathrm{C}$ for $3 \mathrm{~h}$ to decrease the pores [5]. The prepared compacts were employed as working electrodes. The ac impedance tests were examined at customary circumstances and temperatures equal to RT, 300, 400, 500, and $600^{\circ} \mathrm{C}$. By submitting the $2 \mathrm{RQR}$ corresponding circuit (Fig. 7), ZVIEW software was used to fit the measurement data. The impedance plots acquired at diverse temperatures are designated in Fig. 8a-e.

The outcomes are employed for estimating the conductivity values and they are demonstrated in Table 6. It pursues that nanocomposite exhibits superior conductivity values at elevated temperatures $\left(400-600^{\circ} \mathrm{C}\right)[7,46,47]$.

The activation energy of the prepared sample has been computed dealing with Eq. 1 via the Arrhenius linear fit connection.

$\sigma_{d c}(T)=\sigma_{o} \exp \left(-E_{a} /\left(K_{B} T\right)\right.$

Table 7 summarizes the computed activation energies values. Finally, when the conductivity amplifies, the activation energy also increases up.
Using Arrhenius data, it was expected that the ionic conductivity of doped ceria electrolyte materials is stimulated not alone by the concentration and the lattice strain, but also by the allocation of oxygen vacancy levels [48]. From this, it was revealed that partial replacement of Gadolinium with $\mathrm{CeO}_{2}$ could lead to two reverse consequences. Firstly, it is the containment of the organization of the oxygen vacancy levels and which could cause a reduction in the activation energy of conduction and growth in the ionic conductivity [49]. Secondly, it is the deviance of the lattice constant from pure ceria and which might cause to enlarge in the activation energy (conductivity) and the reduction (ionic conductivity) [50]. Consequently, the electrolyte with greater ionic conductivity and poorer activation energy ought to be with a suitable dopant level.

\section{Conclusion}

In this study, $\mathrm{Ce}_{1-\mathrm{x}} \mathrm{Gd}_{1-\mathrm{y}} \mathrm{O}_{2-\delta}-\mathrm{Ce}_{1-\mathrm{x}} \mathrm{Sm}_{-\mathrm{y}} \mathrm{O}_{2-\delta}[\mathrm{x}=0.8, \mathrm{y}=0.2]$ nanocomposite was productively synthesized by coprecipitation route. TGA pattern reveals the approach to acquire phase pure nanocomposite powder. The XRD spectrum exhibits a crystalline structure whereas SEM/ EDAX studies prove the sphere-shaped morphology of the S-CGO nanocomposite with particle size differing from 40 to $70 \mathrm{~nm}$ and the chemical composition present in the prepared sample as per the requirement without any impurities respectively. The typical peaks of the FTIR spectrum express the occurrence of the $\mathrm{M}-\mathrm{O}$ bond in the material. The determined conductivity of the sintered sample proposes that it could be proficiently employed as an electrolyte substance in LT-SOFC systems.

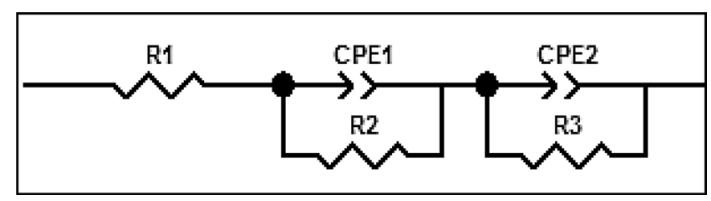

Fig. 7 Corresponding circuit (2RQR) employed for fitting the data 
(a)

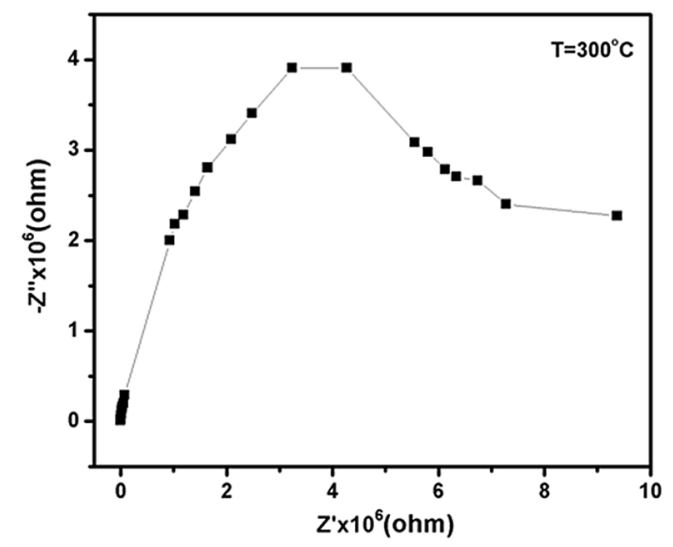

(b)

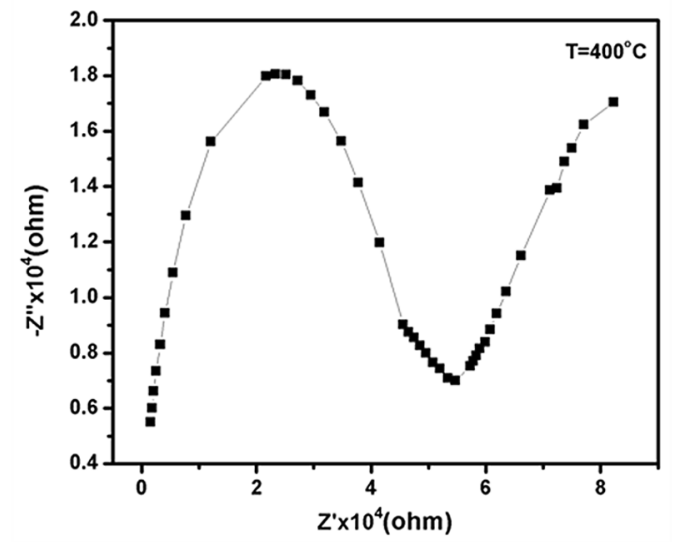

(c)

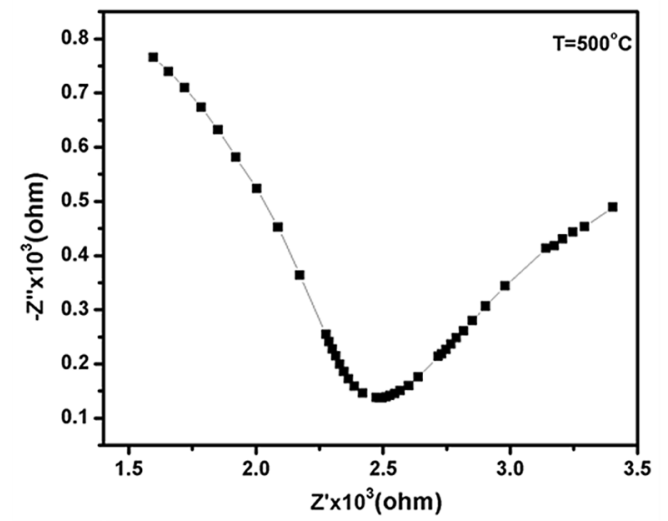

(d)

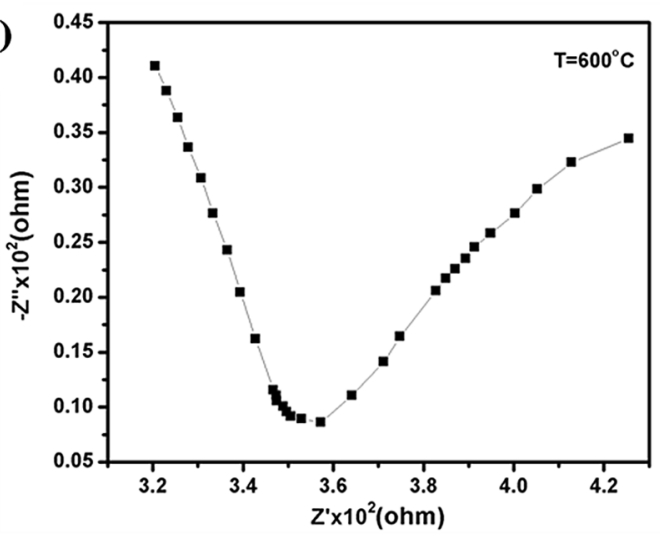

(e)

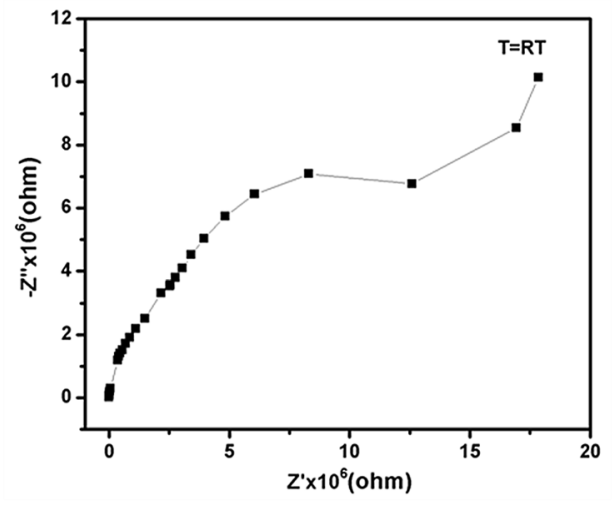

Fig. 8 Impedance plots of the prepared nanocomposite at diverse temperatures

Table 6 Computed

conductivity values for nanocomposite at diverse temperatures

\begin{tabular}{ll}
\hline $\begin{array}{l}\text { Tem- } \\
\text { perature } \\
\text { (K) }\end{array}$ & Conductivity $(\mathrm{S} / \mathrm{cm})$ \\
\hline RT & $7.0156 \times 10^{-09}$ \\
573 & $1.7361 \times 10^{-08}$ \\
673 & $2.7550 \times 10^{-06}$ \\
773 & $5.7031 \times 10^{-05}$ \\
873 & $3.9771 \times 10^{-04}$ \\
\hline
\end{tabular}


Table 7 Computed activation energies of the prepared sample

\begin{tabular}{llllll}
\hline Material & $\begin{array}{l}\text { Tempera- } \\
\text { ture }(\mathrm{K})\end{array}$ & $1000 / \mathrm{T}\left(\mathrm{K}^{-1}\right)$ & Log $\sigma \mathrm{T}\left(\mathrm{Scm}^{-1} \mathrm{~K}\right)$ & Slope & Activation energy $(\mathrm{eV})$ \\
\hline S-CGO & 673 & 1.492 & -5.807 & -6.317 & 0.544 \\
& 773 & 1.298 & -4.872 & & \\
& 873 & 1.149 & -4.265 & & \\
\hline
\end{tabular}

\section{Compliance with ethical standards}

Conflicts of interest The authors declare no conflict of interest.

\section{References}

1. Artini C, Pani M, Carnasciali MM, Flaisier JRP, Costa GA (2016) Lu-, Sm- and Gd-doped ceria: a comparative approach to their structural properties. Inorg Chem 55:10567-10579

2. Xie Shenkun, Liu Ying, Xi Wenguang, Zhou Defeng, Meng Jian (2017) Effect of Nd/Mg co-doping on the electrical properties of ceria-based electrolyte materials. Mater Res Innov 21:69-73

3. Karthik K, Nikolova Maria P, Anukorn Phuruangrat S, Pushpa V, Revathi M Subbulakshmi (2020) Ultrasound-assisted synthesis of $\mathrm{V}_{2} \mathrm{O}_{5}$ nanoparticles for photocatalytic and antibacterial studies. Mater Res Innov 24(4):229-234. https://doi.org/10.1080/14328 917.2019.1634404

4. Karthik K, Pushpa S, Madhukara Naik M, Vinuth M (2019) Influence of $\mathrm{Sn}$ and $\mathrm{Mn}$ on structural, optical and magnetic properties of spray pyrolysed CdS thin films. Mater Res Innov 24(2):8286. https://doi.org/10.1080/14328917.2019.1597436

5. Karthik K, Revathi V, Tatarchuk Tetiana (2018) Microwaveassisted green synthesis of $\mathrm{SnO}_{2}$ nanoparticles and their optical and photocatalytic properties. Mol Cryst Liq Cryst 671(1):17-23. https://doi.org/10.1080/15421406.2018.1542080

6. Artini C (2018) RE-doped ceria systems and their performance as solid electrolytes: a puzzling tangle of structural issues at the average and local scale. Inorg Chem 57:13047-13062

7. Madhuri C, Venkataramana K, Nurhayati A, Vishnuvardhan Reddy C (2018) Effect of $\mathrm{La}^{3+}$ and $\mathrm{Pr}^{3+}$ co-doping on structural, thermal and electrical properties of ceria ceramics as solid electrolytes for IT-SOFC applications. Curr Appl Phys 18:1134-1142

8. Artini C, Locardi F, Pani M, Nelli llaria, Caglieris Federico, Masini Roberto, Plaisier Jasper Rikkert, Costa Giorgio Andrea (2017) $\mathrm{Yb}$-doped $\mathrm{Gd}_{2} \mathrm{O}_{2} \mathrm{CO}_{3}$ : structure, microstructure, thermal and magnetic behaviour. J Phys Chem Solids 103:59-66

9. Arabaci A (2015) Effect of Sm and Gd dopants on structural characteristics and ionic conductivity of ceria. Ceram Int 41:5836-5842

10. Liu Yanyan, Fan Liangdong, Cai Yixiao, Zhang Wei, Wang Baoyuan, Zhu Bin (2017) Superionic conductivity of $\mathrm{Sm}^{3+}, \mathrm{Pr}^{3+}$ and $\mathrm{Nd}^{3+}$ triple-doped ceria through bulk and surface two-step doping approach. ACS Appl Mater Interfaces 928:23614-23623

11. Presto $S$, Artini $C$, Pani MM, Carnasciali S, Massardo M Viviani (2018) lonic conductivity and local structural features in $\mathrm{Ce}_{1-\mathrm{x}} \mathrm{Sm}_{\mathrm{x}} \mathrm{O}_{2-\mathrm{x} / 2}$. Phys Chem Chem Phys 20:28338-28345

12. Coles-Aldridge AV, Baker RT (2018) lonic conductivity in multiply substituted ceria-based electrolytes. Solid State lon 316:9-19

13. Zhang L, Meng J, Yao F, Zhang W, Liu X, Meng J, Zhang H (2018) Insight into the mechanism of the ionic conductivity for In-doped ceria ( $\mathrm{Ln}=\mathrm{La}, \mathrm{Pr}, \mathrm{Nd}, \mathrm{Pm}, \mathrm{Sm}, \mathrm{Gd}, \mathrm{Tb}, \mathrm{Dy}, \mathrm{Ho}$, $\mathrm{Er}$, and $\mathrm{Tm}$ ) through first-principles calculation. Inorg Chem 57:12690-12696

SN Applied Sciences

APRINGER NATURE journa
14. Karthik Kannan D, Radhika Kishor Kumar, Sadasivuni Maria $P$, Nikolova Hakimeh Mahdizadeh, Verma Urvashi (2020) Structural studies of bio-mediated $\mathrm{NiO}$ nanoparticles for photocatalytic and antibacterial activities. Inorg Chem Commun 113:107755

15. Babu AS, Bauri R, Srinivas Reddy G (2016) Processing and conduction behavior of nanocrystalline Gd-doped and rare earth co-doped ceri electrolytes. Electrochim Acta 209:541-550

16. Artini C, Pani M, Carnasciali MM, Buscagila MT, Plaiser JR, Costa GA (2015) Structural features of Sm- and Gd-doped ceria studied by synchrotron $X$-ray diffraction and $\mu$-Raman spectroscopy. Inorg Chem 54:4126-4137

17. Artini C, Carnasciali MM, Viviani M, Presto S, Plaiser JR, Coasta GA, Pani M (2018) Structural properties of Sm-doped ceria electrolytes at the fuel cell operating temperatures. Solid State Ion 315:85-91

18. Coduri M, Masala P, Allieta M, Peral I, Brunelli M, Biffi CA, Scavini $\mathrm{M}$ (2018) Phase transformations in the $\mathrm{CeO}_{2}-\mathrm{Sm}_{2} \mathrm{O}_{3}$ system: a multiscale powder diffraction investigation. Inorg Chem 57:879-891

19. Karthik Kannan D, Radhika AS Nesaraj, Namitha R (2019) Costeffective method of Co-doped rare earth-based ceria (Y-CGO) nanocomposite as electrolyte for LT-SOFCs using C-TAB as surfactant. Mater Res Innov. https://doi.org/10.1080/14328 917.2019.1706032

20. Jasmine Ketzial J, Radhika Devi, Samson Nesaraj A (2013) Low temperature preparation and characterization of doped $\mathrm{BaCeO}_{3}$ nanoparticles by chemical precipitation. Int J Ind Chem 4:1-10

21. Namitha R, Radhika D, Krishnamurthy G (2019) Hydrothermally synthesized carbon nanotubes for electrochemical hydrogen storage application. Issues Chem Chem Technol 3:30-34

22. Dell'Agli G, Spiridigliozzi L, Pansini M, Accardo G, Yoon SP, Frattini $D$ (2018) Effect of the carbonate environment on morphology and sintering behaviour of variously co-doped ( $\mathrm{Ca}, \mathrm{Sr}, \mathrm{Er}, \mathrm{Pr})$ Samarium-doped ceria in co-precipitation/hydrothermal synthesis. Ceram Int 44:17935-17944

23. Ghelich R, Keyanpour-Rad M, Youzbashi AA, Khakpour Z (2015) Comparative study on structural properties of NiO-GDC nanocomposites fabricated via electrospinning and gel combustion processes. Mater Res Innov 19:44-50

24. Arabaci A (2018) Synthesis and characterization of Pr/Gd codoped ceria by using the citric acid-nitrate combustion method. Solid State lonov 326:69-76

25. Radhika D, Kannan K, Nesaraj AS, Namitha R (2019) Facile low-temperature synthesis and application of $\mathrm{La}_{0.85} \mathrm{Sr}_{0.15} \mathrm{Co}_{0.85} \mathrm{Fe}_{0.15} \mathrm{O}_{3-\delta}$ as superior cathode for LT-SOFCs Using C-TAB as surfactant. Mater Res Innov 10:12. https://doi. org/10.1080/14328917.2019.1686858

26. Radhika Devi, Nesaraj AS (2014) Chemical precipitation and characterization of multicomponent perovskite oxide nanoparticles-possible cathode materials for low temperature solid oxide fuel cell. Int J Nano Dimension 5:1-10

27. Radhika Devi, Samson Nesaraj A (2013) Low temperature chemical precipitation and characterization of ceria based ceramic composite oxide materials. J Metals Mater Miner 23(1):67-77

28. Kannan Karthik, Sivasubramanian Dhanuskodi, Seetharaman Prabukumar, Sivaperumal Sivaramakrishnan (2020) Structural 
and biological properties with enhanced photocatalytic behaviour of CdO-MgO nanocomposite by microwave-assisted method. Optik 204:164221

29. Chitsaz Ata, Jalilpour Marzieh, Fathalilou Mohammad (2013) Effects of PVP and CTAB surfactants on the morphology of cerium oxide nanoparticles synthesized via co-precipitation method. Int J Mater Res 104(5):511-514

30. Gao Z, Mogni LV, Miller EC, Railsback JG, Barnett SA (2016) A perspective on low temperature solid oxide fuel cells. Energy Environ Sci 9:1602-1644

31. Zheng Y, Shi Y, Gu H, Gao L, Chen H, Guo L (2009) La and Ca codoped ceria-based electrolyte materials for IT-SOFCs. Mater Res Bull 44(8):1717-1721

32. Tao Y, Shao J, Wang J, Wang WG (2009) Morphology control of $\mathrm{Ce}_{0.9} \mathrm{Gd}_{0.1} \mathrm{O}_{1.95}$ nano powder synthesized by sol-gel method using PVP as a surfactant. J Alloy Compd 484(1-2):729-733

33. Wolcyrz M, Kepinski $L$ (1992) Rietveld refinement of the structure of $\mathrm{CeOCl}$ formed in $\mathrm{Pd} / \mathrm{CeO}_{2}$ catalyst: notes on the existence of a stabilized tetragonal phase of $\mathrm{La}_{2} \mathrm{O}_{3}$ in La-Pd-O system. Solid state Chem 99:409-413

34. Fuentes RO, Baker RT (2008) Synthesis and properties of gadolinium-doped ceria solid solutions for IT-SOFC electrolyte. Int J Hydrogen Energy 33(13):3480-3484

35. Babu AS, Bauri R (2013) Rare earth co-doped nanocrystalline ceria electrolytes for intermediate temperature solid oxide fuel cells (IT-SOFC). ECS Trans 57:1115-1124

36. Rodriguez-Reinoso F, Mc Enaney et al. (2002) Studies in surface science and catalysis - characterization of porous solids VI, Elsevier: The Netherlands 144:107-113

37. Revathi V, Karthik K (2019) Physico-chemical properties and antibacterial activity of Hexakis (Thiocarbamide) Nickel (II) nitrate single crystal. Chem Data Collect 21:100229

38. Intaphong $\mathrm{P}$, Phuruangrat $\mathrm{A}$, Karthik $\mathrm{K}$ et al (2020) Effect of $\mathrm{pH}$ on phase, morphology and photocatalytic properties of $\mathrm{BiOBr}$ synthesized by hydrothermal method. J Inorg Organomet Polym 30:714-721

39. Shah S, Shah M, Shah A (2020) Evolution in the membranebased materials and comprehensive review on carbon capture and storage in industries. Emergent Mater 3:33-44

40. Hussain Z, Ojha R, Martin LL, Bond AM, Ramanathan R, Bansal V (2019) Controlling the morphological and redox properties of the CuTCNQ catalyst through solvent engineering. Emergent Mater 2:35-44

41. Karthik K, Dhanuskodi S, Gopinath C, Sivaramakrishnan S (2017) Antibacterial activities of CdO microplates synthesized by hydrothermal method. Int J Innov Res Sci Eng 2(1):558-561

42. Karthik K, Victor Jaya N, Kanagaraj M, Arumugam S (2011) Temperature-dependent magnetic anomalies of $\mathrm{CuO}$ nanoparticles. Solid State Commun 151(7):564-568

43. Tas AC, Majewski PJ, Aldinger F (2000) Chemical preparation of pure and strontium- and/or magnesium-doped lanthanum gallate powders. J Am Ceram Soc 83:2954-2966

44. Chandrappa Kusuma G T (2019) Effect of calcination temperature on characteristic properties of $\mathrm{CaMoO}_{4}$ nanoparticles. J Sci Adv Mater Dev 4:150-157

45. Venkataramana K, Madhuri C, Madhusudan C, Suresh Reddy $Y$, Bhikshamaiah G, Vishnuvardhan Reddy C (2018) Investigation on $\mathrm{La}^{3+}$ and $\mathrm{D}^{\mathrm{y} 3+}$ co-doped ceria ceramics with an optimized average atomic number of dopants for electrolytes in IT-SOFCs. Ceram Int 44:6300-6310

46. Artini Cristina, Gigli Lara, Pani Maria Maddalena Carnasciali Marcella (2019) Effect of the (Nd, Dy)-double doping on the structural properties of ceria. Inorganics 7:94

47. Gupta M, Shirbhate S, Ojha P, Smita A (2018) Processing and conductivity behavior of La, Sm, Fe singly and double doped ceria: as electrolytes for IT-SOFC. Solid State lon 320:199-209

48. Kannan K, Sadasivuni KK, Abdullah AM, Kumar B (2020) Current trends in MXene-based nanomaterials for energy storage and conversion system: a mini review. Catalysts 10:495

49. Yamamura H, Katoh E, Ichikawa M, Kakinuma K, Mori T, Haneda $H$ (2000) Multiple doping effect on the electrical conductivity in the $\left(\mathrm{Ce}_{1-\mathrm{x}-\mathrm{y}} \mathrm{La}_{\mathrm{x}} \mathrm{M}_{\mathrm{y}}\right) \mathrm{O}_{2-\delta}(\mathrm{M}=\mathrm{Ca}$, Sr) system. Electrochemistry 68:455-459

50. Yoshida H, Deguchi H, Miura K, Horiuchi M, Inagaki T (2001) Investigation of the relationship between the ionic conductivity and the local structures of singly and doubly doped ceria compounds using EXAFS measurement. Solid State Ionics 140(3-4):191-199

Publisher's Note Springer Nature remains neutral with regard to jurisdictional claims in published maps and institutional affiliations. 